\title{
BIOINDEKS ZOOPLANKTON DI PERAIRAN PULAU BUNAKEN
}

\author{
(zooplankton bioindeks in Bunaken Island Waters)
}

\author{
Kezia K.E. Tampi ${ }^{1 *}$, Joice R.T.S.L Rimper ${ }^{1}$, Veibe Warouw ${ }^{1}$, Frans Lumoindong ${ }^{1}$, \\ Agung, B. Windarto ${ }^{1}$, Medy Ompi ${ }^{1}$, Adnan S. Wantasen ${ }^{2}$,
}

1. Program Studi Ilmu Kelautan, Fakultas Perikanan dan Ilmu Kelautan, Universitas Sam Ratulangi, Manado. 95115, Sulawesi Utara, Indonesia.

2. Program Studi Manajemen Sumberdaya Perairan, Fakultas Perikanan dan IImu Kelautan, Universitas Sam Ratulangi, Manado. 95115, Sulawesi Utara, Indonesia •Corresponding Author: keziakerenerikatampi@gmail.com

\begin{abstract}
The city of Manado has several islands which are strategic places with the development of marine potential. One that is so potential is the waters of Bunaken Island and the forms of activity in Bunaken Island waters vary widely. The purpose of this study is to determine the abundance value and biological index and to analyze the condition of the waters in the waters and to see the comparison at each research station. The results of zooplankton identification consisted of 7 genera including all research stations. The results of the analysis of the highest abundance data were at the third station (8.4822 ind / I) and the lowest abundance value was at the first station (7.4220 ind / I). The results of the biological index analysis obtained are as follows: the average diversity value at three stations is 1.08 , the uniformity is 0.98 and the dominance is 0.20 . The results of the Morisita index for each station are: stations. Which means the value of the distribution pattern is three groups, and the others are uniform in each research genus, the overall distribution is uniform.

Keywords: Zooplankton, Bunaken Island waters, Abundance, Bioindex

Abstrak

Kota Manado terdapat beberapa pulau yang merupakan tempat yang strategis dengan pengembangan potensi kelautan. Salah satu yang begitu potensi adalah Perairan Pulau Bunaken dan bentuk aktivitas yang ada di Perairan Pulau Bunaken sangat bervariasi. Tujuan dari penelitian ini yaitu untuk mengetahui nilai kelimpahan dan indeks biologi serta menganalisis kondisi perairan di perairan dan melihat perbandingan pada masing-masing stasiun penelitian serta menghitung nilai bioindeksnya. identifikasi zooplankton terdiri dari 7 genus sudah termasuk pada semua stasiun penelitian. Hasil analisis data kelimpahan tertinggi ada pada stasiun ketiga (8,4822 ind/l) dan nilai kelimpahan terendah ada pada stasiun pertama $(7,4220 \mathrm{ind} / \mathrm{l})$. Hasil analisis indeks biologi yang diperoleh adalah sebagai berikut: nilai keanekaragaman rata-rata pada tiga stasiun 1,37, keseragaman 0,98 dan dominasi bernilai 0,20. Hasil dari indeks Morisita pada masing-masing stasiun adalah: stasiun. Yang berarti nilai pola sebaran adalah tiga mengelompok, dan yang lainnya adalah seragam pada masing-masing genus penelitian, distribusi keseluruhan adalah seragam.
\end{abstract}

Kata Kunci: Zooplankton, Perairan Pulau Bunaken, Kelimpahan, Bioindeks 


\section{PENDAHULUAN}

Pulau Bunaken merupakan kawasan konservasi serta destinasi wisata yang terletak di teluk Manado, Kota Manado Sulawesi Utara. Pulau ini merupakan salah satu pulau yang terkenal di Indonesia khususnya di Sulawesi Utara yang digunakan sebagai tempat objek wisata. Keindahan dari taman laut Bunaken membuat para turis berdatangan untuk melihat dan bahkan melakukan penelitian. Namun beberapa aktivitas manusia di tempat ini dpat mengurangi tingkat kesubura. Salah satu indicator yang digunakan untuk melihat tingkat kesuburan perairan tersebut adalah zooplankton.

Zooplankton adalah plankton hewani yang hidupnya mengapung, mengambang atau melayang di dalam air yang kemampuan renangnya sangat terbatas hingga selalu terbawa hanyut oleh arus. Zooplankton dikatakan sebagai komunitas yang memiliki peranan yang sangat penting dalam suatu ekosistem perairan yaitu sebagai konsumen primer. Dimana zooplankton dalam ekosistem sebagai konsumer pertama yang memakan fitoplankton, kemudian zooplankton dimakan oleh anak-anak ikan (Yuliana dan Ahmad, 2017).

Kehadiran zooplankton dalam suatu perairan merupakan pengontrol bagi produksi primer fitoplankton. Perubahan lingkungan dan ketersediaan makanan pada suatu perairan akan mempengaruhi zzoplankton. Zooplankton hanya dapat hidup dan berkembang dengan baik pada kondisi perairan yang sehat. Menurut Thoha (2004), jika kondisi lingkungan dan ketersediaan fitoplankton tidak sesuai dengan kebutuhan zooplankton maka zooplankton tidak dapat bertahan hidup dan akan mencari kondisi lingkungan yang sesuai. Tujuan dari penelitian ini yaitu untuk mengetahui nilai kelimpahan dan indeks biologi serta menganalisis kondisi perairan Bunaken dan melihat perbandingan pada masing-masing stasiun penelitian
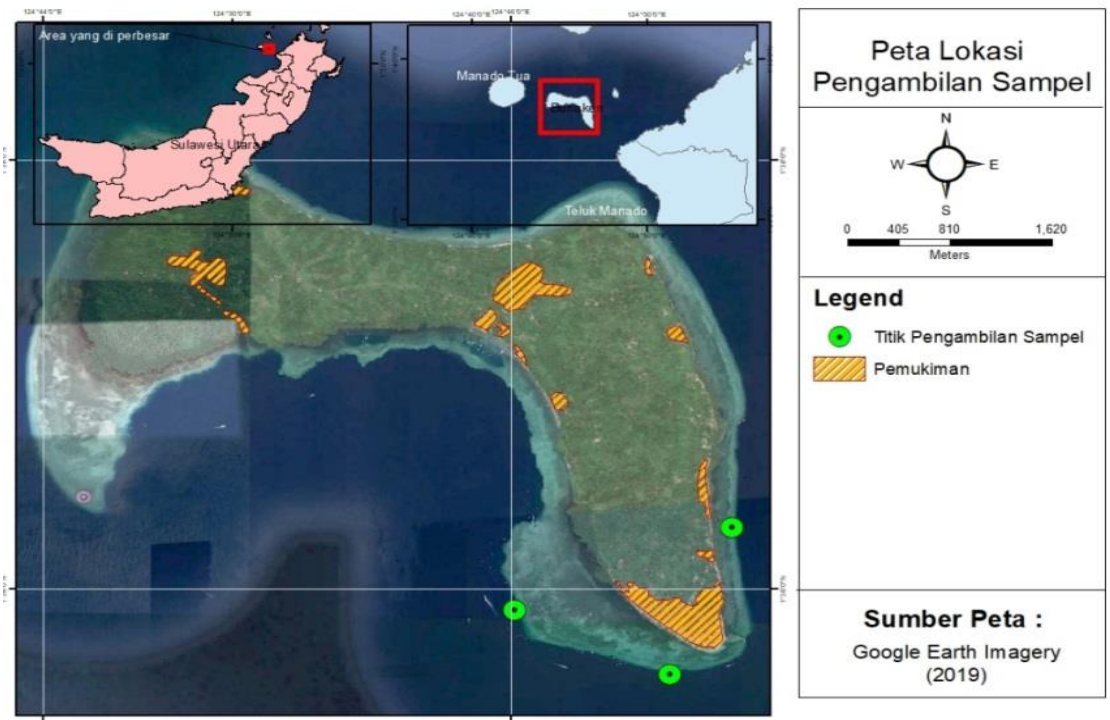

Gambar 1. Peta Lokasi Pengambilan Sampel. 


\section{METODOLOGI PENELITIAN}

Penelitian dilaksanakan pada bulan Mei sampai akhir Juni 2019 dengan berlokasikan di Perairan Pulau Bunaken bagian Selatan, Kota Manado, Provinsi Sulawesi Utara. Sampel yang di ambil di bagi menjadi tiga titik lokasi, lokasi pertama berada di Pangalisang Timur 2, lokasi kedua berada pada dekat Kampung dan lokasi terakhir atau lokasi ketiga berada di Likuan. Identifikasi sampel zooplankton dilakukan di Laboratorium Biologi Kelautan dan Farmasitika Laut, Fakultas Perikanan dan Ilmu Kelautan Universitas Sam Ratulangi Manado. Kemudian dilakukan identifikasi zooplankton mengacu pada buku identifikasi

\section{Pengukuran Parameter Fisika Kimia di Perairan}

pengukuran parameter fisika kimia pada masing-masing lokasi yang telah dilihat kondisi kecerahan cuaca di perairan. Pengukuran ini mencakup pengukuran suhu, $\mathrm{pH}$ dan salinitas air laut. Pengukuran menggunakan alat pengukur sesuai dengan cara penggunaan, dan sampai pada pergerakan angka pada masing-masing alat pengukur. Pengukuran angka yang diperoleh dicantumkan ke dalam catatan sesuai dengan nilai yang didapat pada setiap masing-masing alat pengukur.

\section{Pengambilan Sampel Zooplankton}

Pengambilan sampel plankton dilakukan di tiga stasiun yaitu : Panggalisang Timur 2 (stasiun 1), dekat pemukiman (stasiun 2) dan Likuan (stasiun 3). Sampel plankton diambil menggunakan plankton net, ditarik secara horizontal sepanjang 10 meter, dengan kedalaman sekitar 0,5 meter. Sampel kemudian dimasukkan dalam botol sampel, kemudian diberi label lokasi pengambilan dan diawetkan dengan larutan formalin $4 \%$. Selanjutnya diidentifikasi di laboratorium. Masing-masing lokasi pengambilan sampel dilakukan pengulangan sebanyak tiga kali.

\section{Identifikasi Zooplankton}

Masing-masing botol yang sudah diberi label diaduk secara perlahan menggunakan pipet sebanyak $1 \mathrm{ml}$ dari botol sampel yang ada kemudian dimasukkan ke dalam sedwick rafter untuk kemudian ditutup menggunkan gelas objek. Pengamatan genus zooplankton di mikroskop menggunakan perbesaran40x dan 100x.

\section{Analisis Data}

\section{Kelimpahan Zooplankton}

Perhitungan kelimpahan zooplankton, berdasarkan rumus APHA (APHA, 1989) yaitu:

$$
\mathrm{N}=\mathbf{n} \times(\mathrm{Vr} / \mathrm{Vo}) \times(\mathbf{1} / \mathrm{Vs})
$$

Dimana

$\mathrm{N}=$ Jumlah individu per liter

$\mathrm{n}=$ Jumlah individu yang diamati $\mathrm{Vo}=$ Volume air diamati pada sedwick rafter $(1 \mathrm{ml})$

$\mathrm{Vr}=$ Volume air yang tersaring dalam cod end

$\mathrm{Vs}=$ Volume air yang disaring

Sebelum melakukan perhitungan kelimpahan zooplankton, akan diawali

$$
V s=\pi r^{2} \mathrm{~d}
$$

dengan perhitungan volume air yang tersaring dengan menggunakan rumus : dengan keterangan sebagai berikut:

$\mathrm{Vs}=$ Volume air yang tersaring

$\pi=3,141592654$

$\mathrm{R}=$ Radius mulut plankton net

$\mathrm{d}=$ Panjang lintasan 
Indeks keanekaragaman

Merupakan indeks untuk menilai keseragaman antar spesies dalam komunitas. Indeks ini E (eveness) dihitung dalam rumus berikut :

$$
\mathrm{E}=\frac{H^{\prime}}{H \max }
$$

Dimana perhitungan $\mathrm{H}$ max yaitu $H_{\max }=1 \mathrm{n} \mathrm{S}$

Keterangan:

$\mathrm{E}=$ Indeks Keseragaman

$H^{\prime}=$ Indeks keanekaragaman

$\mathrm{S}=$ Jumlah Spesies

\section{Indeks Dominasi}

Dipakai untuk menentukanberapa besarnya nilai dominasi spesies didalam suatu komunitas. Indeks ini popular dikenal sebagai "Indeks Simpson" dengan persamaan sebagai berikut:

$$
C=\Sigma(\mathrm{Pi})^{2}
$$

\section{Indeks Morisita}

Analisis sebaran dilakukan pada pengambilan data penelitian di Perairan Pulau Bunaken. Data lapangan berupa titik koordinat pada masing-masing pengambilan zooplankton. Analisis pola sebaran zooplankton menggunakan indeks Morisita yang terstandar (standardized Morisita's index) (Morisita 1962 dalam Krebs 1998). Indeks tersebut dihitung dengan persamaan:

$$
\mathrm{Id}=\mathrm{n} \frac{\left[\sum x^{2}-\sum \mathrm{x}\right]}{\left[\left(\sum x\right)^{2}-\sum \mathrm{x}\right]}
$$

Keterangan:

Id = Indeks Morisita

$\mathrm{N}=$ Jumlah plot

$\sum \mathrm{x}=$ Jumlah individu yang ditemukan pada setiap genus
Pola sebaran di tujukkan melalui perhitungan $\mathrm{Mu}$ dan Mcsebagai berikut :

$$
\begin{aligned}
& \mathrm{Mu}=\frac{\chi^{2} 0.95-\mathrm{n}+\sum x i}{\left(\sum x_{\mathrm{i}}\right)-1} \\
& \mathrm{Mc}=\frac{\chi^{2}{ }_{0.05}-\mathrm{n}+\sum x i}{\left(\sum x_{\mathrm{i}}\right)-1}
\end{aligned}
$$

Keterangan:

$\mathrm{Mu}=$ Indeks morisita untuk pola sebaran seragam

$\chi^{2}{ }_{0.975}=$ nilai Chi-Squere tabel dengan derajat bebas n-1dan selang kepercayaan $95 \%$

Mc = Indeks morisita untuk pola searan mengelompok

$\chi^{2} \quad{ }_{0.025}=$ nilai Chi-squere tabel dengan derajat bebas n-1 selang kepercayaan $0.5 \%$

Berdasarkan hasil indeks $\mathrm{Mc}$ atau $\mathrm{Mu}$ di atas maka indeks Morisita standar (Ip) dihitung berdasarkan salah satu dari empat

1. Jika Id $\geq \mathrm{Mc}>1: \mathrm{Ip}=0,5+0.5 \underline{(\mathrm{Id}-\mathrm{Mc})}$

(n-Mc)

2. Jika $\mathrm{Mc}_{\mathrm{c}}>\mathrm{Id} \geq 0: \mathrm{Ip}=0,5(\mathrm{Id}-1)$

$$
\text { (Mu- 1) }
$$

3. Jika $1>\mathrm{Id}>\mathrm{Mu}: \mathrm{Ip}=-0,5(\mathrm{Id}-1)$

$\overline{\mathrm{Mu}-1)}$

4. Jika $1>\mathrm{Mu}>\mathrm{Id}: \mathrm{Ip}_{\mathrm{p}}=-0,5+0,5(\underline{\mathrm{Id}-\mathrm{Mu})}$

(Mu)

persamaan berikut ini:

Indeks Morisa atau pola sebaran ditentukan berdasrakan standarkan (Ip) ini berkisar antara -1 hingga 1 . Jika Ip $=0$ maka pola penyebaran acak. Jika Ip $<0$ maka pola penyebaran seragam dan jika Ip $>0$ maka pola penyebaran mengelompok. 


\section{HASIL DAN PEMBAHASAN}

\section{Parameter Fisika Kimia}

Hasil pengukuran parameter fisika kimia di perairan mencakup suhu, salinitas serta $\mathrm{pH}$ adalah sebagai berikut:

Tabel 1. Parameter fisika kimia di Perairan Pulau Bunaken

\begin{tabular}{|cccc|}
\hline Parameter & \multicolumn{3}{c|}{ STASIUN } \\
Fisika Kimia & $\mathbf{1}$ (PT) & $\mathbf{2}(\mathbf{D K})$ & $\mathbf{3}(\mathbf{L})$ \\
\hline Suhu & $29,1^{\circ} \mathrm{C}$ & $29,3^{\circ} \mathrm{C}$ & $29,1^{\circ} \mathrm{C}$ \\
Salinitas & $26 \%$ \% & $28 \%$ o & $27 \%$ o \\
PH & 7 & 7 & 7 \\
\hline
\end{tabular}

Berdasarkan tabel diatas (Tabel 1) dapat dilihat bahwa kisaran suhu yang diperoleh antara stasiun 1-3 berkisar antara 29,1 - 29,3 ${ }^{\circ} \mathrm{C}$. Dari stasiun 1-3 kisaran suhu yang di peroleh tidaklah jauh berbeda ini dapat menjelaskan adanya kemerataan suhu pada perairan laut Bunaken tersebut, didukung oleh pengaruh distribusi cahaya matahari yang cukup merata pada setiap lokasi perairan serta perkembangan zooplankton. Menurut Rey dan Rao (1964) dalam Agung (2016) menyatakan secara umum suhu optimal berkembangan perkembangan plankton ialah 20-30 ${ }^{\circ} \mathrm{C}$. Pernyataan lain juga menjelaskan bahwa menurut Kadir, $d k k$. (2015), nilai suhu yang optimal untuk zooplankton berkisar antara $25-30{ }^{\circ} \mathrm{C}$ sehingga hasil suhu yang di dapat adalah pada penelitian ini merupakan kisaran suhu optimal bagi pertumbuhan plankton.

Salinitas yang diperoleh disemua stasiun tidak menunjukkan perbedaan yang signifikan, yaitu berkisar antara 26-28 \%o. Salinitas yang di dapatkan masih dalam kisaran yang baik untuk pertumbuhan zooplankton. Menurut Nontji (1993) dalam zooplankton yang telah diuraikan pada tabel sebagai berikut:
Fatuhtohman $d k k$. (2016), sebaran salinitas dipengaruhi oleh beberapa faktor yaitu pola sirkulasi air, Evaporasi (penguapan), Persipitasi (curah hujan), dan aliran sungai (Run off). Nilai salinitas merupakan salah satu yang berpengaruh dalam kondisi lingkungan perairan. Sesuai yang dikemukakan Sachlan (1980) dalam Tambaru $d k k$. (2018). Bahwa salinitas yang sesuai untuk perkembangan zooplankton adalah di atas $20 \%$. Salinitas seperti itulah yang menyebabkan zooplankton dapat bertahan hidup dan memperbanyak diri.

Pengukuran derajat keasamaan $(\mathrm{pH})$ juga memperlihatkan bahwa hasil yang di dapat pada ketiga stasiun tersebut yaitu sama di setiap zona penelitian. Nilai ini masih dalam kisaran normal untuk perairan laut dan sebagian besar biota akuatik disuatu perairan dengan kisaran 78,5 . Batas toleransi toleransi terhadap $\mathrm{pH}$ bervariasi, $\mathrm{pH}$ yang ideal untuk kehidupan zooplankton 6,5-8. Menurut Effendi (2000) dalam Tambaru $d k k$. (2018), sebagian besar biota perairan termasukzooplankton sensitive terhadap perubahan $\mathrm{pH}$ dan menykai nilai $\mathrm{pH}$ sekitar 7-8,5. Menurut Damar (2012) fluktuasi $\mathrm{pH}$ sangat dipengaruhi oleh proses respirasi yang dilakukan oleh plankton. Semakin banyak karbondioksida yang dihasilkan dari proses respirasi, maka $\mathrm{pH}$ akan rendah. Namun sebaliknya jika aktivitas fotosintesis semakin tinggi maka akan menyebabkan $\mathrm{pH}$ semakin tinggi.

\section{Hasil Analisis data Kelimpahan Zooplankton \\ Hasil identifikasi zooplankton terdiri dari beberapa spesies dengan kelimpahan}


Tabel 2. Kelimpahan zooplankton di Perairan Pulau Bunaken

\begin{tabular}{cccc}
\hline No & Stasiun & Jumlah Taksa & Kelimpahan (Ind/L) \\
1 & Stasiun 1 & 20 & 7,4220 \\
2 & Stasiun 2 & 23 & 8.1288 \\
3 & Stasiun 3 & 24 & 8,4822 \\
\hline
\end{tabular}

Berdasarkan tabel di atas (Tabel 2), hasil analisis perhitungan kelimpahan zooplankton berkisar antara yang paling rendah dari stasiun 1 - stasiun 3 adalah 7,4220-8,4822 ind/l. Kelimpahan zooplankton tertinggi ada pada stasiun ke tiga $(8,4822$ ind/l) dengan jumlah genera sebanyak 24 , diikuti oleh stasiun kedua dengan jumlah genera $(8,1288$ ind/l $)$ dengan jumlah genera 23, dan dilanjutkan pada lokasi ketiga yang memiliki nilai kelimpahan terendah $(7,4220 \mathrm{ind} / \mathrm{l})$ dengan jumlah genera 21. Dari keseruhan hasil kelimpahan zooplankton yang ada di tabel di atas memperlihatkan stasiun 1 adalah stasiun terendah dan kemudian stasiun 3 adalah paling tinggi dengan hasil zooplankton yang paling mendominasi di perairan Pulau Bunaken.

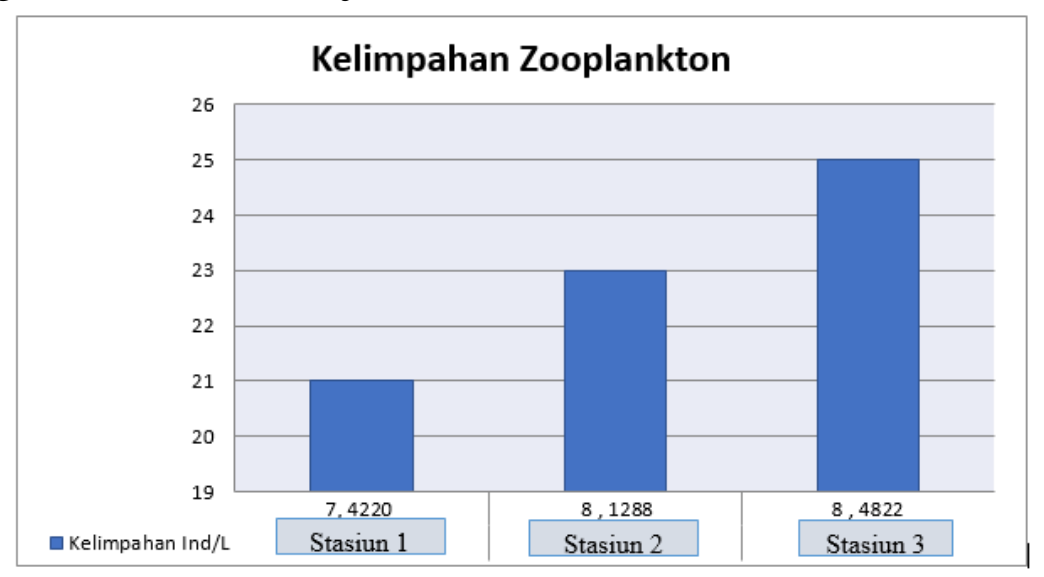

Gambar 2. Kelimpahan Zooplankton di Perairan Pulau Bunaken

Pada setiap stasiun dari stasiun 1-3 dapat di lihat perbedaan yang sangat nyata pada nilai kelimpahan zooplankton. Hal ini terjadi karena daerah pada stasiun pertama itu adalah jauh dari daerah pemukiman dan disitu zooplankton yang ada tidak terlalu mendominasi, di lanjutkan pada stasiun kedua merupakan perairan yang berdekatan dengan daerah penduduk distasiun dua mulau banyak zooplankton, dan pada staisun ke tiga bisa dilihat adalah zooplankton yang paling banyak mendominasi perairan Bunake. Dari hasil kelimpahan, sudah sangat terlihat jelas hasil yang didapat pada stasiun 1-3 yang paling rendah adalah stasiun 1dan kemudian meningkat dari stasiun 2 dan juga stasiun 3 . 


\section{Komposisi Zooplankton Serta Pengaruhnya di Perairan}

Berdasarkan Tabel 2. Dapat dilihat bahwa distribusi zooplankton pada ketiga stasiun tidak merata hanya terdapat 7 genera yaitu Calanus, Nauplius, Cyclops, Harpacticoida, Misophrioida, Arcatia Clausi, Lernea. Diduga ketujuh genera ini beradaptasi dengan baik. Menurut Prionto; Husnah dan Aprianti, 2013 Jenis yang dapat beradaptasi dengan baik dengan lingkungannya akan mendominasi wilayah tersebut. merupakan "grazer" atau pemakan fitoplankton dimana selanjutnya energi yang dihasilkan akan dimanfaatkan oleh organisme tingkatan diatasnya dalam hal ini adalah ikan teri (Dinisia, $d k k$. 2015). Sub kelas Copepoda yang ditemukan pada penelitian ini adalah 95\% dari seluruh komunitas zooplankton di Perairan Bunaken sesuai dengan pernyataan Wiadnyana (1996) bahwa kelompok copepoda dapat dianggap sebagai unsur yang dapat mewakili komunitas zooplankton karena kelompok tersebut sering mendominasi komunitas zooplankton pada berbagai perairan.

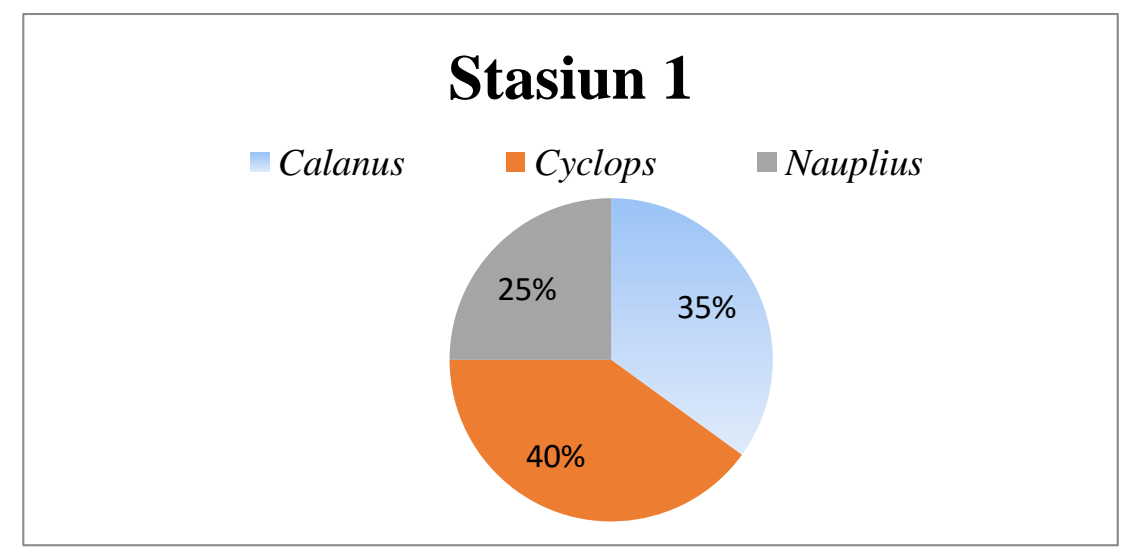

Gambar 3. Persentase komposisi zooplankton pada stasiun 1

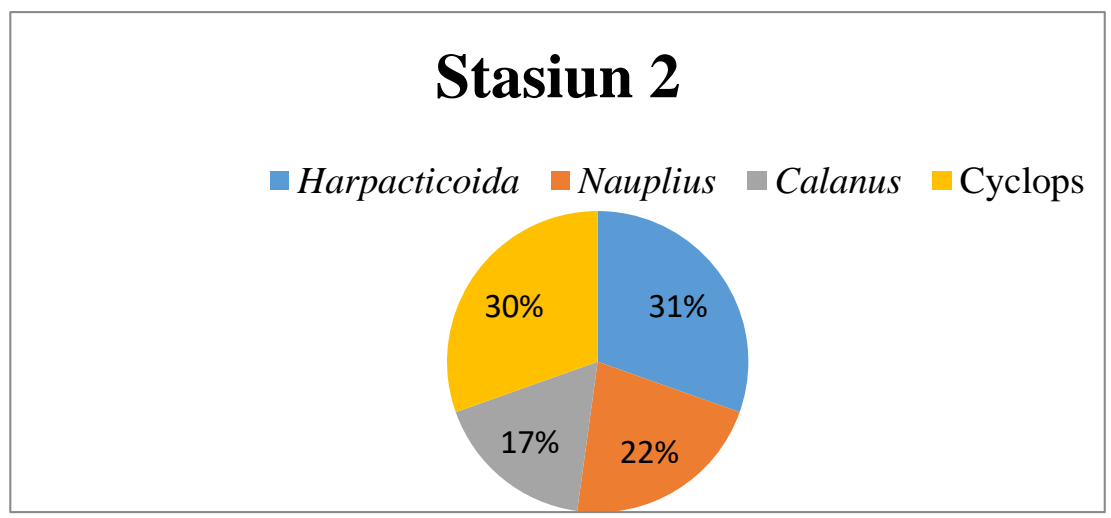

Gambar 4. Persentase komposisi zooplankton pada stasiun 2 
Gambar 5. Persentase komposisi zooplankrton pada stasiun 3

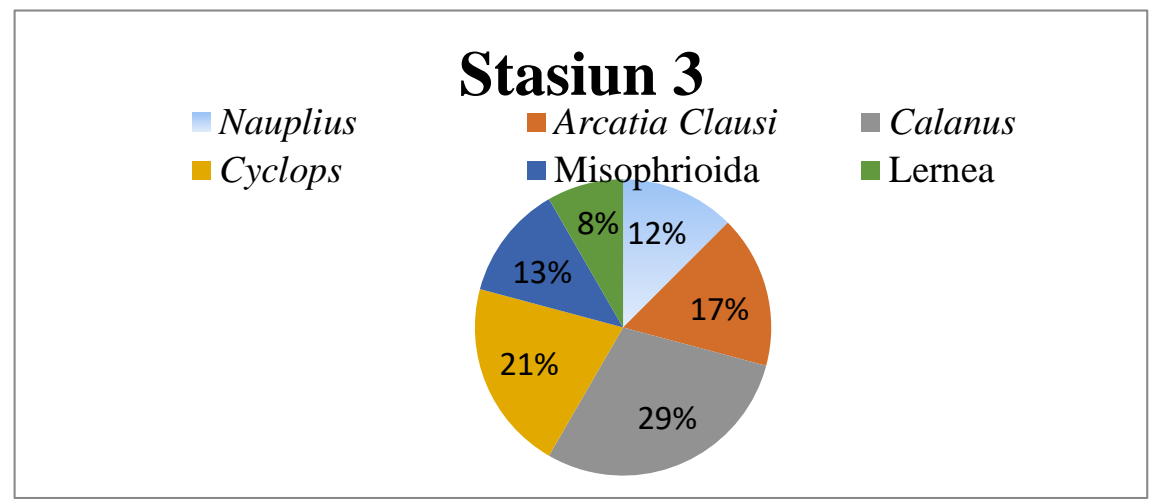

Pada sub kelas Copepoda terdapat di semua stasiun pengamatan dengan jumlah terbanyak dari semua genus yang ada. Hal ini dapat diartikan bahwa melimpahnya sub kelas Copepoda sangat mempengaruhi kondisi perairan tersebut karena zooplankton sendiri adalah salah satu bagian dari rantai makanan. Ini sejalan dengan Eloire $d k k$, (2010) yang menjelaskan bahwa sub kelas Copepoda melimpah diperairan pesisir dengan nilai $85 \%$ dari total zooplankton. Hal ini terkait dengan banyaknya komposisi sub kelas
Copepoda secara total dibandingan dengan kelompok zooplankton yang lainnya (Fitriya, 2011)

\section{Indeks Biologi Zooplankton}

Berdasarkan hasil analis indeks biologi zooplankton, nilai rata-rata indeks keaneragaman adalah 1,1 Keseragaman 0,8 dan dominasi 0,2 dengan masing-masing indeks yang diperoleh dapat di lihat pada tabel 3

Tabel 3. Indeks biologi zooplankton di Perairan Pulau Bunaken

\begin{tabular}{ccccc}
\hline No & INDEKS BIOLOGI & & STASIUN & \\
& ZOOPLANKTON & $\mathbf{1}$ & $\mathbf{2}$ & $\mathbf{3}$ \\
\hline 1 & Keanekaragaman & 1,08 & 0,99 & 0,20 \\
2 & Keseragaman & 0,98 & 0,71 & 0,11 \\
\hline 3 & Dominasi & 0,20 & 0.11 & 0,11 \\
\hline
\end{tabular}




\section{Indeks Keanekaragaman Zooplankton}

Berdasarkan tabel diatas (Tabel 3), indeks keanekaragaman tertinggi ada pada stasiun pertama didukung dengan nilai dominasi yang bisa di katakana lebih rendah pada stasiun tersebut. Namun demikian nilai rata-rata keanekaragaman dan keseragaman pada keseluruhan stasiun penelitian termasuk dalam keragaman rendah. Menurut Krebs (1998), jika nilai $H^{\prime}>1$ maka menyatakan bahwa nilai keanekaragaman dan kestabilan komunitas lebih besar sehingga hasil yang didapat pada pengamatan di perairan Pulau Bunaken yaitu tergolong keanekaragaman yang cukup baik. Malara 2019 mengatakan keanekaragaman tertinggi ada pada stasiun 1 dengan hasil keakeragaman tertinggi ada pada nilai $H^{\prime}=1,08$ dan yang terendah terdapat pada stasiun 3 dengan nilai $H^{\prime}=$ 0,20 dan dapat di lihat hasil yang di dapat pada indeks keanekaragaman ini yang paling rendah teredapat pada stasiun 3 dengan nilai indeks keanekaragaman yakni dengan nilai $H^{\prime}=0,20$.

\section{Indeks Keseragaman}

Indeks keseragaman dapat dilihat bahwa hasil dari zooplankton menunjukkan nilai yang tidak terlalu rendah pada semua stasiun yang ada dengan jumlah nilai yang tidak jauh berbeda antara stasiun satu dengan stasiun yang lainnya. Indradewa 2019 mengatakan bahwa semakin kecil E menunjukkan semakin kecil pula keseragaman zooplankton, maka itu berarti penyebaran individu tiap genus tidak sama dan memiliki kecenderrungan bahwa ada suatu genus yang mendominasi populasi tersebut. Berdasarkan data yang di dapat, maka keseragaman dinyatakan komunitas dalam kondisi saat ini labil - stabil.

\section{Indeks Dominasi}

Berdasarkan tabel indeks biologi (Tabel 3), nilai yang didapat pada indeks dominasi berada pada kisaran 0,11 - 0,20 dalam hal ini memperlihatkan biota yang tidak terlalu mendominasi. Umumnya apabila pada suatu komunitas perairan memiliki nilai $H^{\prime}$ dan E yang tinggi, maka nilai D yang cenderung rendah. Sebaliknya apabila nilai $H^{\prime}$ dan E yang rendah, maka nilai $D$ yang tinggi menunjukkan ada dominasi suatu spesies terhadap spesies lain dan dominasi yang cukup besar akan mengarah pada komunitas yang labil atau tertekan, (Masrizal dan Azhar (2001). Organisme dalam suatu stasiun dapat dikatakan mendominasi jika nilai indeks Dominasinya sangat kuat dan mendekati angka 1 (Krebs,1989) dalam Sara (2019). Menurut Odum (1993) menyatakan bahwa hilangnya suatu jenis yang dominan akan menimbulkan perubahan-perubahan penting tidak hanya komunitas biotiknya sendiri tetapi akan juga dalam lingkungan fisiknya. Adanya dominasi suatu jenis zooplankton dapat diindikasikan perairan tersebut sudah tercemar atau kurang baik, sehingga hanya jenis tertentu yang dapat beradaptasi pada kondisi perairan tersebut. Dominasi jenis suatu organisme salah satu indicator untuk menilai salah satu kualitas perairan. 


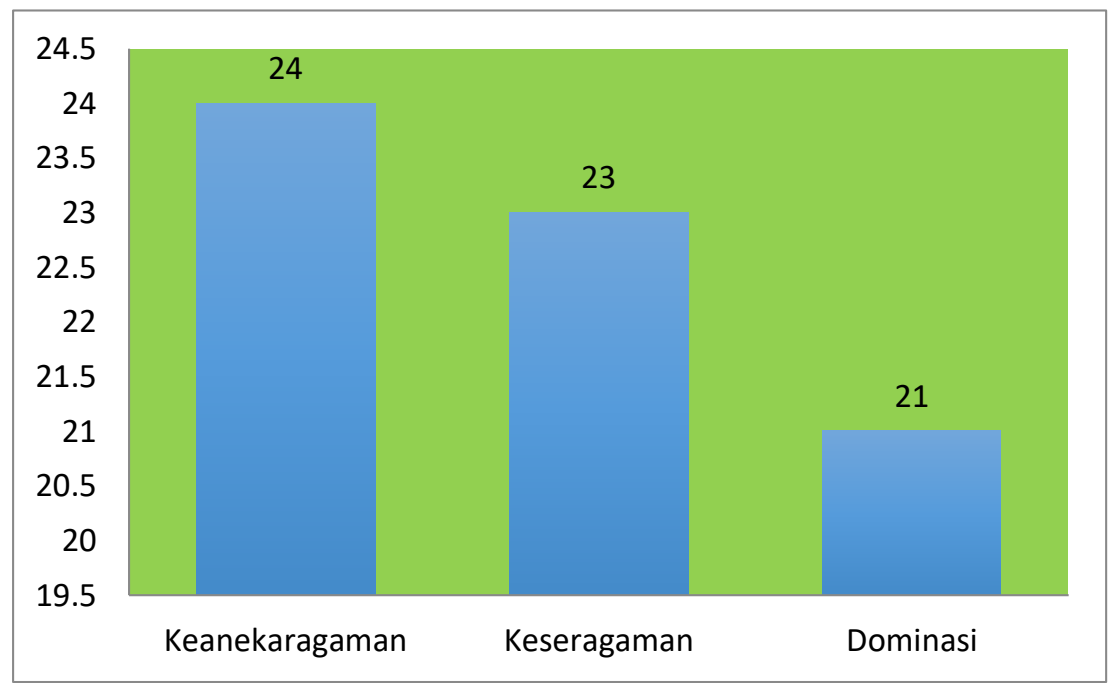

Gambar 6. Nilai rata-rata indeks biologi pada ke tiga stasiun Penelitian.

\section{Hasil Nilai Indeks Morisita}

Tabel 4. Hasil perhitungan nilai indeks morisita

\begin{tabular}{|c|c|c|}
\hline $\begin{array}{c}\mathbf{N} \\
\mathbf{0}\end{array}$ & $\begin{array}{c}\text { INDEKS MORISITA } \\
\text { ZOOPLANKTON }\end{array}$ & Nilai \\
\hline 1 & Stasiun 1 & 1.283 \\
\hline 2 & Stasiun 2 & 0.989 \\
\hline 3 & Stasiun 3 & 0.903 \\
\hline
\end{tabular}

Berdasarkan hasil yang di dapat dalam perhitungan nilai indeks morisita pada tabel diatas (Tabel 4), memperlihatkan bahwa nilai pada stasiun 1-3 terdapat 7 spesies yang ditemukan pada lokasi penelitian memiliki distribusi mengelompok (lp > 0). Dari setiap hasil nilai indeks morisita memperlihatkan bahwa semua dari stasiun 1-3 memiliki pola sebaran yang mengelompok dan tidak menunjukkan perubahanan yang signifikan pada setiap stasiun penelitian. Hal ini memberikan interpretasi bahwa semua stasiun memiliki nilai yang yang tidak jauh berbeda pada setiap spesies dan di stasiun penelitian.
KESIMPULAN

Berdasarkan hasil nilai penelitian yang dilakukan, maka dapat disimpulkan bahwa:

1. Hasil pengukuraan parameter fisika kimia di perairan Pulau Bunaken tergolong normal yaitu : $29.1^{\circ} \mathrm{C}-29.3$ ${ }^{\circ} \mathrm{C}$, salinitas $26 \%$ - $28 \%$ dan $\mathrm{pH} 7$ pada semua stasiun penelitian.

2. Hasil identifikasi zooplankton di tiga stasiun pengamatan ditemukan 7 jenis yaitu Calanus, Cyclops, Harpacticoida, Misophrioida, Acartia Clausi, Lernea dan Nauplius.

3. Kelimpahan tertinggi yaitu di stasiun 3 $(8,4822$ ind/l) dan kelimpahan terendah di stasiun 1 (7,4220 ind/l). Indeks keanekaragaman tertinggi di stasiun 1 yaitu 1,08 ; stasiun 2 yaitu 0,99 dan terendah di stasiun 3 yaitu 0,20 . Zooplankton paling mendominasi ada di stasiun pertama. Untuk nilai indeks morisita di stasiun 1 - 3 tergolong mengelompok dengan nilai 1.283-0.903. 


\section{DAFTAR PUSTAKA}

Dinisia, A., Adiwilaga, E.M., Yonvitner. 2015. Kelimpahan Zooplankton dan Biomasa Ikan Teri (Stolephorus spp.) pada Bagan di Perairan Kwatisore Teluk Cendrawasih Papua. Jurnal Fisheries. Vol. 6 (2) : 143-154

Fahturohman, I., Sunarto., dan I. Nurruhwati. 2016. Korelasi Kelimpahan Plankton Dengan Suhu Perairan Laut di Sekitar PLTU Cirebon. Jurnal Perikanan Kelautan. Vol 7. No 1. Hal: 118.

Fitriya, N., Abiba, I. W., \& Mulyadi (2011). Komposisi Copepoda di Perairan Barau, Kalimantan Timur. Oseanologi dan Mimnologi di Indonesia, 37(2), 355368.

Kadir, M. A., \& Krisanti, M. (2015). Dinamika Spesial dan Temporal Struktur Komunitas Zooplankton di Teluk Jakarta. Jurnal Ilmu Pertanian Indonesia, 20(3), 247-256.

Masrizal dan Azhar.2001. Kajian dan Keanekaragaman Jenis Ikan pada Ekosistem Perairan di Taman Nasional Kerinci Seblat. Pusat Studi Lingkungan Hidup UNAND Padang. Naskah Proposal yang diajukan kepada Yayasan KEHATI, Padang $20 \mathrm{p}$.

Odum, E.P. 1993. Dasar - Dasar Ekologi. Edisi ketiga. Gajah mada UniversityPress. Jogjakarta. H. 134-162

Sara A., X. Th. L. Lalamentik., A., B., Rondonuwu., Struktur Komunitas Lamun (Seagrass) di Perairan Pantai Kelurahan Molas, Kecamatan Bunaken Kota Manado Sulawesi Utara. Hal: 51.
Widiadnyana, NN. 1996. Kondisi Plankton di Perairan Sekitar Pulau Biak dan Teluk Cenderawasih, Irian Jaya. Buletin Ilmu Kelautan TORANI. 6(2)

Yuliana, I. (1976). Komposisi Jenis dan Kelimpahan Zooplankton di Perairan Teluk Buli, Halmahera Timur. Jurnal Ilmiah Agribisnis Perikanan, 10 (2) : 44-50. 